\title{
Methodology of Transforming Digital Competence Framework to Curricula: Croatian e-Schools Project Example
}

\author{
V. Kirinić, R. Mekovec, and N. Žajdela Hrustek
}

\begin{abstract}
In 2015 the programme entitled "e-Schools: A comprehensive informatization of school operation and teaching processes with the aim of creating digitally mature schools for the 21st century" started in Croatia. The results of the pilot project e-Schools include a Digital Competence Framework for School Employees: Teachers, Principals and Administrative Staff, and based on this, the Curriculum for the Enhancement of Digital Competences of School Employees: Teachers, Principals and Administrative Staff. In the paper, the methodology of transforming the Digital Competence Framework to Curricula is described: from digital competencies expected from school staff, through learning outcomes (units) to the modules and implementation/instruction units to be used as the base for educating school staff and helping them to achieve and/or improve their own digital competencies.
\end{abstract}

Index Terms-Curricula, digital competence framework, methodology, school.

\section{INTRODUCTION}

"e-Schools: A comprehensive informatisation of school operation processes and teaching processes aimed at the creation of digitally mature schools for the 21 st century" [1] is a Croatian programme, financed mostly (85\%) from the Structural Funds of the European Union. It consists of the pilot project, implemented in the period 2015-2018 and involving 150 primary and secondary schools (or about $10 \%$ of Croatian schools), and the major project, which will be implemented in the period 2019-2022 and will encompass at least 850 schools. The project coordinating body is the Croatian Academic and Research Network - CARNet, a public institution that operates under the Ministry of Science, Education and Sports and the only academic institution involved in the project is the Faculty of Organization and Informatics, University of Zagreb.

"The purpose of the e-Schools pilot project is to establish a system for the development of digitally mature schools through the pilot project and the evaluation of the application of ICT in the educational and operational processes of $10 \%$ of schools in the Republic of Croatia" [1].

One of the main goals of the Strategy of Education, Science and Technology of the Republic of Croatia [2] is to "develop programs and educate teachers for the use of ICT in learning and teaching, including for the development of digital

Manuscript received April 15, 2018; revised July 3, 2018.

The authors are with the Faculty of Organization and Informatics, University of Zagreb, Varaždin, Croatia (e-mail: valentina.kirinic@foi.hr, renata.mekovec@foi.hr,nikolina.zajdela@foi.hr). educational content" which, within the e-School project is manifested, among the other, in the preparation of the curriculum for the advancement of digital competences of three groups of users in schools: teachers and associates, principals and administrative staff. These three groups of users include the following jobs:

1) Teachers and associates - includes jobs: teacher, psychologist, pedagogue, librarian and educational rehabilitation worker,

2) Principals - includes the executive staff of the school,

3) Administrative staff - includes jobs: secretary, accounting manager / accounting officer and administrative employee.

One of the fundamental issues in developing curricula for the acquisition of digital competences by these three groups of users was the identification of the core of knowledge and skills which should have all group of users regardless of theirs involvement in process of teaching. Looking at the aspect of digital competencies, they primarily relate to the ability to learn and teach with ICT. This requires fast adaptation to a new technical and technological environment, understanding of one's own role in a new environment, and a valid self-evaluation and understanding of one's own achievements in terms of personal professional advancement. Due to the complexity of the curriculum for the acquisition of digital competences, the first challenge was to define the most appropriate solution of theoretical concepts and curriculum design to meet the above-mentioned requirements. The curriculum is the basis for further project activities: (1) to develop the educational content and (2) implementation of the education of beneficiaries and (3) the evaluation of the development of their digital competence.

Under the concept of curriculum, Vladimir Jurić [3] implies extensive planning, organization and verification of the learning process (teaching) with regard to the corresponding detailed objectives, content elements, organization of learning and teaching and control of achievement of learning according to globally set goals and assumptions for learning.

\section{LITERATURE OVERVIEW}

Many European countries have started curricular reform of their education systems. A basic characteristic of newly created education curricula is that the development of student competence is central to them, especially competence regarding the use of digital technologies. Today's digital technologies allow teachers as well as students not only to use 
digital content for learning and teaching but also to become active creators of digital educational content. Therefore, integration of ICT and the Internet in classrooms and the importance of learning and teaching through ICT and the Internet is unquestionable. One of the most important factors of successful implementation is the digital competence that must be provided, in part, by the students themselves, but primarily by the teachers and other staff employed in the educational institution, including principals, professional associates and administrative staff.

One of the fundamental questions is how to fulfil this necessary need for a permanent adoption of the core of knowledge and skills with the contemporary demands of a continuously changing social environment requiring constant improvement, and sometimes replacement of certain competencies with new ones. The answer is a lifelong learning that covers the activities of all forms of all learning that is done permanently with a view to improving knowledge, skills and competences for personal, social and professional needs. A key component of the lifelong learning policy of the European Commission is adult education, which directly affects the competitiveness and employability of individuals, social inclusion, active citizenship, and in particular personal development of the individual.

\section{A. Characteristics of Curriculum Development for Adult Education}

Given that the focus of this paper is explaining the transformation of the digital competence framework into curriculum and related to adult education, it is important to define the term of an adult. Adult is a person who has reached physical and intellectual maturity, or a person who is biologically, mentally, socially and professionally mature [4]. When viewed from the aspect of education, an adult is considered to have passed through a certain form of formal education (elementary, high school, higher education, scientific education) as well as certain forms of informal education. Delors [5] points out that the basic idea of adult education starts from the assumption that individuals are considered responsible, competent and active. Accordingly, when it comes to curriculum development that is designed for adult education, it is important at the very beginning to develop an analysis of user competencies for which the curriculum is being prepared and to analyse their needs and the requirements of their business environment and profession. One of the essential goals of adult education is to gain insight into features and opportunities, individual characteristics, anticipations, aspirations, wishes and expectations of the users themselves. Therefore, according to Purković [6], it is very important to design a measuring instrument (questionnaire) that can be used to assess the possession of the competences, interests, wishes and expectations of each user. Applying the results of such a measuring instrument at the very beginning of the process can serve as a good guide for defining activities, designing materials and elaborating possible individualized content as well as selecting the most suitable way of teaching potential users [6]. In addition to this initial measuring instrument (questionnaire), the content and the form of adult education may also be determined by questionnaires or self-assessment of learning styles [7], [8].
According to Purković [6], methodological elaboration of curriculum parts intended for adult education should take into account three very important criteria: adaptation utility, anticipative utility and transferability. Adaptation utility refers to the appreciation of previous knowledge and the needs of potential curriculum users. Anticipative utility refers to user skills development through tasks and activities that are of a problem nature so that users have to work independently or in teams to solve the problem. The purpose of this is to successfully identify the problem situation in the working environment and to find an appropriate way to solve the problem. One of the most important criteria is transferability, which would mean that the curriculum needs to follow the needs of the user and be applicable directly for the purpose of carrying out tasks and activities in a particular business or life environment and situation.

It follows from all of the above that content as well as the activities envisaged in the curriculum intended for adult education should be focused more on the acquisition of practical knowledge and skills rather than the teaching of theoretical facts and content. Therefore, the evaluation of the users when viewed from the aspect of adult education should be devised in a way that is more formative without excluding a summative evaluation at the end of education. The information that can be obtained using formative evaluation methods can serve to assess the adoption of the knowledge and skills of the training user and be the guiding information for planning further steps in the education.

Evaluation of users defined in the curriculum should be focused on the application of methods that encourage independent monitoring, reflection and self-perception of the acquisition of knowledge and skills and taking responsibility for their own progress as well as use of the same in private and business practice. In doing so, the use of formative evaluation methods during training is also useful to educators as a feedback for planning future teaching and for improving the teaching process. A great role in collecting information on student achievements during training and creating feedback and suggestions for better knowledge and skills also has evaluation methods such as peer evaluation, e-portfolio, or team formation collaboratively evaluating their learning effects [9] as well as methods of critical friendship [10] and realization of action research [11]. As one of the most important activities of curriculum operationalization, evaluation of the achievements of the beneficiary stands out, which can be achieved by summative evaluation. For the implementation of the evaluation, an appropriate measuring instrument should be designed and constructed, which should be aimed at evaluating the applied procedural knowledge and cognitive skills on the basis of verbal or written examination of knowledge and skills or practical work or demonstration of acquired skills. Such a measuring instrument should provide both, training users and educators with final feedback on the success of the training, while also, serving as an educator for revising existing training materials as well as activities and foreseeable problematic tasks designed for the purpose of training.

The curriculum characteristics of adult learning, teaching and evaluation have been described so far to provide insight into the reasons why it is also recommended that the 
curriculum should be of an open type and consist primarily of a series of recommendations and guidelines, or recommended forms of performance, recommended learning and teaching activities and recommended monitoring and evaluation activities, not a strictly dictated program. Ornstein and Hunkins [12] emphasize that this approach requires that teachers (training managers) understand it well and that they have developed the necessary competences in interaction with the learners. Finally, it is important to note that the quality of education will not depend so much on the quality of the curriculum itself, how much it will depend on the choice of those who will apply it.

\section{B. Overview of Previous Research and Curriculum}

The basis for the design of the proposed curriculum, basic modules and performance units as well as defined learning outcomes covering the critical mass of digital competencies necessary to perform the work of the three groups of users was the Framework for the Digital Competence of Schools [13] together with the Manual for Framework for the Digital Competence of Schools [14] and the Croatian Qualification Framework [15].

In addition to the above mentioned basic literature, a number of relevant sources related to education in the area of digital competence have been used to define how to acquire both theoretical and practical knowledge and skills in the business environment for daily work tasks and for performing everyday life activities. One of the key sources used is the "Media and Information Literacy Curriculum for Teachers" created by the UNESCO working group [16], which was made up of a number of international experts. This curriculum was largely used to cover areas related to information and media literacy. The curriculum itself presents a number of different strategies and examples of good practices in the specified area. The mentioned curriculum attempted to integrate these two areas through topics such as information needs, access, evaluation, organization and ethical issues related to the use of information and information and communication technology. Among other things, it also serves to underline the importance of the role of new media, a critical review of new media content, the importance of individual expression as part of democratic participation and the importance of the skills which people need to be able to create their own media content.

The courses that served as the relevant source of information for curriculum development are the DIGICOMP Online Course for Teachers [17], which includes a number of modules covered by this curriculum, namely areas related to information, communication, security, problem solving and content creation. In the part of the competence related to information literacy, a document titled "Information Literacy Standards for Teacher Education" [18] was also consulted for teachers, librarians and faculty staff. These standards are designed as a guide for faculty teachers and librarian education in the development of teaching skills for teacher and librarian competences in the field of information literacy, among others. They are recommendations for teachers to integrate information literacy into future curricula, work assignments and evaluation activities.

The ECDL curriculum documents related to text and image processing tools [19]-[21] spreadsheets [22], [23], presentation tools [24], [25], digital photography [26], tools for the creation of audiovisual content [27], [28] have been consulted in the curriculum area for the promotion of digital competences related to digital content development, and a separate module designed to acquire knowledge and skills related to the use of ICT in education [29].

Part of the Australian Curriculum [30] related to the ICT Capability (ICT Capabilities) was used for the area of technical problems: 1.) Communication via ICT, 2.) ICT-based creation, 3.) ICT Research, 4.) Application of Social and Ethical Protocols and Practices in Using ICT, and 5.) ICT Management and Business.

Since all participants in the teaching process encounter the acquisition and use of already created content, the authorship rights and permissions which should be introduced to the teaching staff are of major importance. To create modules and performance units in this area, the Berklee Online curriculum related to the Copyright Act [31] was consulted (Bargfrede, Berklee Online).

Regarding the topic of copyright issues, a document issued by the American University Library [32] entitled "What Faculty Need To Know About Copyright for Teaching" was also used for explaining and answering questions about copyright, how long copyright law has been held, which materials can be used for teaching purposes and how, in what situations you do not have to ask for permission from the owner, how to use copy materials that are copyrighted, and many other issues related to teaching and use of copyrighted material. For the adequate description of the module in this area, sources of the State Intellectual Property Office of the Republic of Croatia [33] were also used.

For the area which covers competencies related to programming, CODE Studio web pages [34] have been used. CODE Studio web pages offer training for acquiring competences for teaching in the field of information science. A number of lessons provide useful advice and recommendations related to learning and teaching, development of digital materials, and the evaluation of acquired knowledge and skills.

\section{PROBLEM Formulation AND RESEARCH METHOD}

The goal of pilot project e-School is establishment of a system of digitally mature schools anticipating a gradual, voluntary transition to digital content, in which the key role of teachers, associates, principal and administrative staff will be to introduce ICT as a key element of each educational process. "The overall objective of the e-schools programme is to contribute to the capacity building of the primary-school and secondary-school educational system in order to allow students to be prepared for the labour market, further education and lifelong learning" [1].

The authors of Ornstein and Hunkins [12] state three basic curriculum designs: (1) subject-centered designs, (2) learner-centered designs and (3) problem-oriented (problem-centered designs). Student-user-centered design groups include: child-centered designs, experience-centered designs, radical design, and social designs (humanistic 
designs).

The design of this curriculum is based on a student-curriculum-based design, or a humanistic design curriculum design. Humanistic curriculum design takes into account the previous experience, interests and needs of the user or user group that is being created and which is in line with the constructivist approach of learning and teaching. With regard to openness, an open curriculum approach has been chosen, which is characterized by the flexibility of the methodology of production and is based on recommendations that allow creativity and the introduction of change in the course of implementation, since it is a curriculum development for the area of acquisition of digital competences which, like almost no other area today, is subject to continuous changes. According to the previous description, the approach of the open curriculum that is proposed relies on a constructivist approach to learning and teaching.

Learning outcomes are statements of what a learner is expected to know, understand and be able to demonstrate after completion of a learning experience. On the other side, competences represent a dynamic combination of cognitive and meta-cognitive skills, knowledge and understanding, interpersonal, intellectual and practical skills, and ethical values [35]. The main distinction between competency and a learning outcome is that a learning outcome is written so that it can be measured or assessed [36]. The Croatian Qualifications Framework [15] define learning outcomes as the competences acquired by the learner and proven after the learning process. While competencies in this Law are defined as "knowledge and skills and the associated autonomy and responsibility."

A constructivist approach to learning is based on five principles [37]:

- Learning is the process of interaction between what we know and what needs to be learned - it is important to take into account the attitudes of the learners

- Learning is a social process - it is realized through interaction of the participants

- Learning is a situational process - taking an active role in community practice

- Learning is a metacognitive process - it implies learning how to learn

- Learning is based on the participants' activities and autonomy.

For the purpose of possible operationalization of curricula for the advancement of digital competences of three groups of users, basic methodical elaboration of each module and execution unit was performed. The development of the module includes indication of what it is intended for, its purpose, the recommended volume of hours as well as the highest levels of learning outcomes. Each module is subdivided into implementation/instructional units whose further development relates to the definition of goals, recommended topics to be dealt with within each of the defined execution units, the recommended hours, recommended form of execution, recommended teaching and learning activities, with the recommended number of work hours for each activity, learning outcomes at the highest level, and recommended monitoring and evaluation activities. Requirements for material and personnel requirements are also defined.

Defined modules, performance units, and themes along the performance units should continue with the elaboration of specific activities that will encompass each individual education including time duration, prerequisites for realization, necessary learning and teaching materials, and the anticipations and skills needed for each module. The development of certain activities should result in a valid action plan, e.g. a timeline of activities during each individual education.

\section{RESUlts}

As one of the results of the first phase of the project e-Schools, the Digital Competence Framework for School Employees: Teachers and associates, Principals and Administrative Staff was developed [13], defining which competences these three categories of school employees should have with regard to their daily work tasks which they perform supported by digital technologies. The Digital Competence Framework introduces three main dimensions of competences: general digital competences for all target user groups, competences for the educational use of digital technologies by teachers (and associates), and digital competences for school management. General digital competences have mainly evolved from the first version of DigComp [38], having (similar to DigComp) three levels of competence complexity defined: basic, intermediate and advanced. The Digital Competence Framework is accompanied by a handbook [14] with descriptive situational examples of the demonstration of digital competencies in certain types of tasks for each target user group and for all three levels (basic, intermediate and advanced).

In the next phase, the task was to develop the Curriculum for the Enhancement of Digital Competences of School Employees: Teachers and associates, Principals and Administrative Staff, also based on DigComp.

Based on the curriculum, educational content is further produced for delivery in three different forms (F2F workshops, webinars and MOOCs) and accompanying instruments for the assessment of learning outcomes are also developed.

As already mentioned, one of the main e-Schools project results is the Curriculum for the Enhancement of Digital Competences of School Employees: Teachers and associates, Principals and Administrative Staff [39], essentially based on the Digital Competence Framework for School Employees: Teachers and associates, Principals and Administrative Staff [13] (and consequentially on the DigComp) as well as on the Framework for Digitally Mature Schools [40], was prepared by the Faculty of organization and informatics project team.

The curriculum outlines the educational content and defines the learning outcomes, recommended teaching methods, educational models and evaluation methods for the acquisition and enhancement of digital competencies of school employees. It is intended to be used by training providers when creating and delivering educational content and training.

Based on the 36 competencies defined in the Digital Competence Framework, the curriculum defines and 
describes 34 units of learning outcomes incorporated in 17 modules and 42 implementation/instruction units.

Three main groups of competences are introduced:

- General digital competences - 16 units of learning outcomes required for all target user groups;

- Competences for the educational use of digital technology -11 units of learning outcomes required for the category of teachers;

- Digital competences for school management - 7 units of learning outcomes required for school principals.

A. The Methodology of Curriculum for the Enhancement of Digital Competences of School Employees: Teachers and Associates, Principals and Administrative Staff Creation

The creation of the Curriculum for the Enhancement of Digital Competences of School Employees: Teachers and associates, Principals and Administrative Staff, on the basis of the aforementioned and described examples of good practices in the field of digital competences and respect for the Croatian Qualifications Framework, was conducted in the following steps:

1) Defining learning outcomes based on competences and areas defined in the Digital Competence Framework for School Employees. The Unit of Learning Outcomes is based on one or two / more unified competences or one competence is the basis for multiple Unit of Learning Outcomes.

2) Describing learning outcomes through elements presented in Table I: the aim / purpose of the unit of learning outcomes is derived from the description of building competencies. The list of learning outcomes is defined based on the description of building competencies through their elements, at three levels of complexity: initial, intermediate and advanced.

3) Combining Units of Learning Outcomes into modules and implementation/instructional units.

4) Describing Modules and Implementation/instruction Units as shown in Table II and Table III.

5) Drawing up curricula for three groups of users (teaching plans for improving the digital competences of teachers, principals and administrative staff)

\section{B. The Correlation of the Curriculum Modules and Implementation/Instruction Units with the School Digital Maturity Framework}

The digital competence of three groups of users in schools: teachers / teachers and professional associates, directors and administrative staff are prerequisites for achieving digital maturity of schools. The Digital Maturity Framework of the School [40] is the basis for a common understanding of the digital maturity of all stakeholders in the education system and it is necessary to show how the advancement of the digital competences of a school can be applied in order to improve the level of digital maturity of said school. Digitally mature schools are defined by the development of digital competences of educational staff and students. The primary aim of digitally mature schools is that educators use ICT to improve teaching methods, which focus on teaching students, and develop digital educational content and evaluate students' achievements that are consistent with learning outcomes and educational goals. The relationship between the elements of the Digital Maturity Framework of the School [40] and the curriculum modules is also given and presented in the table in the Curriculum [39].

\section{Structure of the Document Curriculum for Improving the Digital competences of Three Groups of Users in Schools: Teachers, Principals and Administrative Staff}

The Curriculum for the improvement of digital competences of three groups of users in schools: teachers and associates, principals and administrative staff contains more than 300 pages in total.

The first chapter describes the purpose and process of creation and the Curriculum document itself, and presents the theoretical bases of the Curriculum as well as defining basic concepts relevant to its understanding.

The Digital Competences described in the Framework of Digital Competencies and the defined learning outcomes as well as the elements of learning outcomes (in the appendix of the Curriculum) are presented in the second chapter.

The third chapter describes the curriculum goal and curricula for each user group in schools summarized in tabular form. Thereafter, the modules and the accompanying implementing/instruction units of the curriculum are described. The digital competence of users in schools is an essential element and indicator of digital maturity of the school and a separate sub-chapter provides an overview of the interdependence of modules and implementation/instruction units for the achievement of digital competences within the areas and elements defined by the Digital Maturity Framework of the School [40].

The fourth chapter provides guidelines for curriculum-based training: the possible forms of performance, the features of adult education / training, the valuation forms and quality assurance elements are also described.

The final parts of the Curriculum Documents are the Glossary, References, and the Appendix describing units of learning outcomes.

The aim of the curriculum is to enable participants to acquire and enhance the digital competences envisaged by the Digital User Competency Framework in the school: teachers / trainers and associates, directors and administrative staff.

\section{CONCLUSION}

The importance of digital technology and digital competencies for both professional and everyday life is unquestionable. It is even greater when digital technology is introduced and used in the school environment. No matter how novel a digital technology is, it is up to people using the technology if it would contribute process and result or product improvement and problem solving. Thus, digital competencies of school staff, in this case, should be considered carefully: their definition, evaluation, as well as their achievements and/or potential improvements.

Creating curricula is a very demanding process, especially when they are intended for adult learners and rapidly changing and demanding content as found in digital technologies. Additionally, when all other aspects, such as projects and requirements, are considered and taken into account, the creation of curricula is even more demanding. 
TABLE I: THE LEARNING OUTCOME UNIT DESCRIPTION

\begin{tabular}{|c|c|c|c|}
\hline Learning outcome unit title & \multicolumn{3}{|c|}{ SIU-R1.4. Learning outcome unit title } \\
\hline Aim/purpose of the learning outcome unit & \multicolumn{3}{|c|}{ Description of the learning outcome unit aim/purpose } \\
\hline $\begin{array}{l}\text { Learning outcome unit level according to } \\
\text { CROQF }\end{array}$ & \multicolumn{3}{|l|}{6} \\
\hline $\begin{array}{l}\text { Proposed volume of the unit of learning } \\
\text { outcomes }\end{array}$ & \multicolumn{3}{|c|}{2 (ECTS) } \\
\hline List of learning outcomes & $\mathrm{Nr}$. & Learning outcome title & Level \\
\hline & & Learning outcome SIU-R.1.4.1. & $\mathrm{B}$ \\
\hline & & Learning outcome SIU-R.1.4.2. & B \\
\hline & & Learning outcome SIU-R.1.4.3. & I \\
\hline & & Learning outcome SIU-R.1.4.4. & B \\
\hline & & Learning outcome SIU-R.1.4.5. & I \\
\hline & & Learning outcome SIU-R.1.4.6. & A \\
\hline $\begin{array}{l}\text { Entrance requirements for acquiring the } \\
\text { learning outcomes }\end{array}$ & \multicolumn{3}{|c|}{ Previously acquired Level 4.2. or higher qualification } \\
\hline $\begin{array}{l}\text { Material and human resources necessary to } \\
\text { acquire the learning outcome unit }\end{array}$ & \multicolumn{3}{|c|}{$\begin{array}{l}\text { Material and human resources necessary to acquire the learning outcome unit } \\
\text { - Classroom of appropriate size, equipped minimally with computer, projector, internet } \\
\text { connection and writing equipment (eg white board or smart board). } \\
\text { - A computer lab equipped minimally with computer for teacher/educator and students, } \\
\text { projector, Internet connection, computer programs and the posibility to use specific servers. } \\
\text { - An e-Learning system with electronic materials and online activities accessible based on the } \\
\text { AAI identity (user account). } \\
\text { - Mass Open Online Course (MOOC) system with electronic materials and online activities } \\
\text { accessible based on the AAI identity (user account). } \\
\text { - A network environment for running and accessing webinars based on the AAI identity (user } \\
\text { account). } \\
\text { - Portal for the access to tools, systems and applications to be used in e-learning and in teaching } \\
\text { and other processes that take place at school. } \\
\text { - A portal for access to and dissemination of digital educational content (DEC) and } \\
\text { teaching/learning scenarios based on the AAI identity (user account). } \\
\text { - Virtual environments for co-operation of students based on the AAI identity (user account). } \\
\text { Human resources necessary to acquire the learning outcome unit } \\
\text { - A teacher or associate who can be a mentor in a particular context (e-learning, MOOC), who is } \\
\text { an expert in the field to which the learning outcome unit belongs. } \\
\text { - Expert (pedagogue, didactic, ...) in the field of application of digital technologies in teaching }\end{array}$} \\
\hline $\begin{array}{l}\text { Material and human resources necessary to } \\
\text { assess the learning outcome unit }\end{array}$ & \multicolumn{3}{|c|}{$\begin{array}{l}\text { Material resources necessary to assess the learning outcome unit } \\
\text { - Depend on the chosen education method and the process for evaluating each individual } \\
\text { learning outcomes } \\
\text { Human resources necessary to assess the learning outcome unit } \\
\text { - A teacher or associate who can be a mentor in a particular context (e-learning, MOOC), who is } \\
\text { an expert in the field in which the learning outcome unit belongs. } \\
\text { - Expert (pedagogue, didactic, ...) in the field of application of digital technologies in teaching }\end{array}$} \\
\hline $\begin{array}{l}\text { Assessment procedures and examples of } \\
\text { assessment for all learning outcomes within the } \\
\text { proposed learning outcome unit }\end{array}$ & \multicolumn{3}{|c|}{$\begin{array}{l}\text { 1. Prepare in writing (or graphic form) the answer to the question: what is ... } \\
\text { 2. Based on the information and guidelines given, determine resources, present their stance... } \\
\text { 3. Set the evaluation criteria individually or in the team for ... and interpret the evaluation results } \\
\text { in written / oral in which (each team member presents her/his own part of the work/result... } \\
\text { 4. Based on the information and guidelines given, determine digital repositories, present their } \\
\text { stance... } \\
\text { 5. Based on the inspection method, determine the opportunities offered by different repositories, } \\
\text { present their stance... } \\
\text { 6. Based on the problem method discuss about digital repositories in the team... and interpret the } \\
\text { evaluation results in written / oral in which (each team member presents her/his own part of the } \\
\text { work/result... }\end{array}$} \\
\hline
\end{tabular}

TABLE II: THE MODULE DESCRIPTION

\begin{tabular}{|l|l|l|}
\hline Title of the module & R1-M-2 Title of the module & $\begin{array}{l}\text { Intended beneficiaries/participants: } \\
\text { teachers } \\
\text { principals } \\
\text { administrative staff }\end{array}$ \\
\hline Purpose of the module & Description of the module purpose \\
\hline $\begin{array}{l}\text { Proposed volume } \\
\text { hours total (hours of training/ guided instruction + } \\
\text { hours of personal learning activity of the participants) }\end{array}$ & $X$ \\
\hline Learning outcomes on the highest level & $\begin{array}{l}\text { 1. Learning outcome 1 } \\
2 . \text { Learning outcome 2 } \\
\ldots\end{array}$ \\
\hline Implementation/instruction units & $\begin{array}{l}R 1-M-2-I C-1 \text { Implementation/instruction unit 1 title } \\
R 1-M-2-I C-2 \text { Implementation/instruction unit 2 title } \\
R 1-M-2-I C-3 \text {... }\end{array}$ \\
\hline
\end{tabular}


TABLE III: THE IMPLEMENTATION/INSTRUCTION UNIT DESCRIPTION

\begin{tabular}{|c|c|c|c|}
\hline $\begin{array}{l}\text { Title of the } \\
\text { implementation/instruction unit }\end{array}$ & \multicolumn{3}{|c|}{ R1-M-2-IC-1 Implementation/instruction unit 1 title } \\
\hline $\begin{array}{l}\text { Aim of the implementation/ } \\
\text { instruction unit }\end{array}$ & \multicolumn{3}{|c|}{$\begin{array}{l}\text { Description of the Implementation unit aim (intended benefit for the teachers, principals, administrative staff: } \\
\text { Acquire knowledge and skills and apply good practices related to ...) }\end{array}$} \\
\hline $\begin{array}{l}\text { Proposed implementation/ } \\
\text { instruction unit topics }\end{array}$ & \multicolumn{3}{|c|}{$\begin{array}{ll}\text { Topic } 1 . & \\
\text { Topic 2. } & \text { Short description of the Topic } 1 . \\
\ldots & \text { Short description of the Topic } 2 .\end{array}$} \\
\hline $\begin{array}{l}\text { Proposed volume } \\
\text { hours total (hours of guided } \\
\text { instruction }+ \text { hours of personal } \\
\text { learning activity of the } \\
\text { participants) }\end{array}$ & \multicolumn{3}{|l|}{$x(y+z)$} \\
\hline $\begin{array}{l}\text { Proposed teaching and learning } \\
\text { activities (recommended hours) }\end{array}$ & \multicolumn{3}{|c|}{$\begin{array}{l}\left.\text { Workshop ( } \mathbf{y}_{\mathbf{1}}\right) \\
\text { Guided activities: } \\
\text { concept presentation and development; discussion / panel discussion - about (own) experiences, } \\
\text { needs and problems; Demonstration and Case Analysis - Examples of Good / Bad Practices, Use of } \\
\text { Digital Technologies; exercise - through making practical work and giving feedback; } \\
\text { collaborative/peer learning - task development (solving realistic problem situations) in the team, } \\
\text { presentation of solutions and their discussion (evaluation of the solution) } \\
\text { knowledge assessment, evaluation questionnaire } \\
\text { Personal activities of the participants: } \\
\text { Webinar ( } \mathbf{y}_{2} \text { ) } \\
\text { Guided activities: } \\
\text { concept presentation and development; discussion / panel discussion - about (own) experiences, } \\
\text { needs and problems; demonstration - examples of good / bad practice, use of digital technologies; } \\
\text { making small-scale practical tasks (e.g. opinion, motivation questionnaires, problem } \\
\text { identification, ...) } \\
\text { knowledge assessment, evaluation questionnaire } \\
\text { Personal activities of the participants: } \\
\text { E-course (z) } \\
\text { Guided activities: } \\
\text { presentation and development of concepts (online conference); discussion / panel discussion (forum } \\
\text { for discussions, online conference); conducted research / project assignment - independently and / or } \\
\text { in teams, the result is monitored and submitted as part of the e-learning activity and evaluated } \\
\text { according to the criteria discussed with the participants and realized through the rubrics); evaluation } \\
\text { (through the process of discussion and criticism within the team define the criteria of analysis, } \\
\text { analyze and interpret the results) } \\
\text { study (consulting of recommended materials and additional sources of information / examples of } \\
\text { good / bad practices; preparation of exercise assignments; discussion and discussion with other } \\
\text { participants; guided research / project tasks - independently and / or in teams; evaluation of } \\
\text { e-learning activities), e-learning contribution and knowledge sharing (creation of repositories of } \\
\text { high-quality sources of information / knowledge, creation of dictionaries, wikis, etc.) }\end{array}$} \\
\hline $\begin{array}{l}\text { Learning outcomes on the highest } \\
\text { level }\end{array}$ & $\begin{array}{ll}\text { 1. } & \text { Learning outcome SIU-F } \\
\text { 2. } & \text { Learning outcome SIU-F } \\
\text { 3. } & \text { Learning outcome SIU-F } \\
\text { 4. } & \text { Learning outcome SIU-F } \\
\text { 5. } & \text { Learning outcome SIU-F } \\
\text { 6. } & \text { Learning outcome SIU-F }\end{array}$ & $\begin{array}{l}\text { R.1.4.1. - B } \\
\text { R.1.4.3. - I } \\
\text { R.1.4.6. - A } \\
\text { R.1.6.6. - I } \\
\text { R.1.6.2. - I } \\
\text { R.1.6.7. - A }\end{array}$ & \\
\hline \begin{tabular}{|r} 
Learning outcome \\
level
\end{tabular} & Basic & Intermediate & Advanced \\
\hline SIU-R1.4. & Learning outcome SIU-R.1.4.1. - B & & \\
\hline SIU-R1.4. & Learning outcome SIU-R.1.4.2. - B & Learning outcome SIU-R.1.4.3. - I & \\
\hline SIU-R1.4. & Learning outcome SIU-R.1.4.4. - B & Learning outcome SIU-R.1.4.5. - I & Learning outcome SIU-R.1.4.6. - A \\
\hline SIU-R1.6. & Learning outcome SIU-R.1.6.5. - B & Learning outcome SIU-R.1.6.6. - I & \\
\hline SIU-R1.6. & Learning outcome SIU-R.1.6.1. - B & Learning outcome SIU-R.1.6.2. - I & \\
\hline SIU-R1.6. & & & Learning outcome SIU-R.1.6.7. - A \\
\hline $\begin{array}{l}\text { Proposed monitoring and } \\
\text { evaluation activities }\end{array}$ & $\begin{array}{l}\text { SIU-R.1.4.1. - B: Prepare in writing } \\
\text { SIU-R.1.4.2. - B: Based on the infor } \\
\text { SIU-R.1.4.3. - I: Set the evaluation cr } \\
\text { in written / oral in which (each team } \\
\ldots\end{array}$ & $\begin{array}{l}\text { (or graphic form) the answer to the } \\
\text { rmation and guidelines given, determ } \\
\text { riteria individually or in the team for . } \\
\text { member presents her/his own part of }\end{array}$ & $\begin{array}{l}\text { uestion: what is ... } \\
\text { ine ... } \\
\text {.. and interpret the evaluation results } \\
\text { the work/result). }\end{array}$ \\
\hline
\end{tabular}


The journey from digital competencies defined in the Digital Competence Framework for School Employees: Teachers, Principals and Administrative Staff, to the Curriculum for the Enhancement of Digital Competences of School Employees: Teachers, Principals and Administrative Staff was long and rough and should be viewed as only the beginning. In the project phases to come, the Curriculum should be improved based on the suggestions and results of all stakeholders (for example, suppliers of school staff training) using the Curriculum to prepare and deliver educational content, school staff as adult learners and recipients of the educational content, as well as the pupils/students who should benefit from the digital technologies used and from the digitally mature schools.

\section{REFERENCES}

[1] CARNet. e-Schools. Project description. [Online]. Available: https://www.e-skole.hr/en/e-schools/project-description/

[2] Strategy of Education, Science and Technology of the Republic of Croatia (NN124/2014), 2014.

[3] Jurić. School curriculum. [Online]. Available: http://www.azoo.hr/images/stories/dokumenti/ravnatelji-materijali/Jur ic_Skolski_kurikulum.ppt

[4] M. Matijević, Learning by Arrangement - Introduction to Adult Education Technology, Zagreb Birotehnika, 2000.

[5] J. Delors et al., "Learning: Treasure in us," UNESCO Report International Commission for the Development of Education for the 21st Century, Zagreb: Educa, 1998.

[6] D. Purković, "Constructivist approach to the operationalization of the curriculum of technical culture," Pedagogical Research, vol. 10, pp. 1, pp. 49-64, 2013.

[7] R. M. Felder and L. K. Silverman, "Learning and teaching styles in engineering education," Journal of Engineering Education,. vol. 78, no. 7, pp. 674-681, 1988.

[8] L. K. Litzinger, S. H. Lee, J. C. Wise, and R. M. Felder, "A psychometric study of the index of learning styles," Journal of Engineering Education, vol. 96, no. 4, pp. 309-319, 2007.

[9] J. Hattie, Visible Learning for Teachers: Maximizing Impact on Learning, New York: Routledge, 2012.

[10] A. L. Costa and B. Kallick, "Through the lens of a critical friend," Educational Leadership, vol. 51, pp. 49-51, 1993.

[11] B. Bognar, 'Initiating teachers' action research: Empowering teachers' voices," Educational Journal of Living Theories, vol. 6, pp. 1-39, 2013.

[12] A. Ornstein and F. Hunkins, Curriculum Design, Boston, MA: Pearson/Allyn and Bacon, 2009.

[13] Framework for the Digital Competence of Schools. E-schools. (2016). [Online].

Available: https://www.e-skole.hr/wp-contentuploads/2016/12/OKVIR_digitalne _kompetencije-4.pdf

[14] Handbook for Framework for the Digital Competence of Schools. E-schools. (2016). [Online]. Available: https://www.e-skole.hr/wp-content/uploads/2016/12/PRIRUCNIK_di gitalne_kompetencije-1.pdf

[15] Croatian Qualifications Framework. [Online]. Available: http://narodne-novine.nn.hr/clanci/sluzbeni/2013_02_22_359.html

[16] UNESCO. (2011). Media and Information Literacy Curriculum for Teachers. [Online]. Available: http://unesdoc.unesco.org/images/0019/0019 29/192971e.pdf

[17] DIGICOMP. (2015). Digital Competences for Teachers. [Online]. Available: http://www.digital-competences-for-teachers.eu/

[18] College \& Research Libraries News, "Information literacy standards for teacher education: Approved by the ACRL board of directors," Association of College \& Research Libraries, vol. 72, no. 7, pp. 420-436, 2011.

[19] (2007). ECDL / ICDL Image Editing. Syllabus Version 2.0, ECDL. [Online]. Available: http://ecdl.org/media/imageediting.pdf

[20] (2007). ECDL/ICDL Word Processing. Syllabus Version 5.0, ECDL. [Online]. Available: http://ecdl.org/media/wordprocessing.pdf

[21] (2008). ECDL / ICDL Advanced Word Processing, ECDL. [Online]. Available: http://ecdl.org/media/advanced_wordprocessing.pdf

[22] (2007). ECDL / ICDL Spreadsheets. Syllabus Version 5.0, ECDL. [Online]. Available: http://ecdl.org/media/spreadsheets.pdf
[23] (2008). ECDL / ICDL Advanced Spreadsheets, ECDL. [Online]. Available: http://ecdl.org/media/advanced_spreadsheets.pdf

[24] (2007). ECDL / ICDL Presentation. Syllabus Version 5.0, ECDL [Online]. Available: http://ecdl.org/media/presentation.pdf

[25] (2008). ECDL / ICDL advanced presentation, ECDL. [Online]. Available: http://ecdl.org/media/advanced_presentation.pdf

[26] (2014). Digital photography, Entry Level 3 Syllabus, BCS. [Online] Available:

http://www.bcs.org/upload/pdf/digital-skills-digital-photographysylla bus.pdf?utm_source=website\&utm_campaign=website

[27] (2014). Audio and Video Software, Entry Level 3 Syllabus, BCS [Online].

Available: http://www.bcs.org/upload/pdf/digital-skills-audio-video-software-syl labus.pdf?utm_source=website\&utm_campaign=website

[28] (2014). Digital Music, Entry Level 3 Syllabus, BCS. [Online]. Available:

http://www.bcs.org/upload/pdf/digital-skills-digital-music-syllabus.p df

[29] (2015). ECDL/ICDL e ICT in Education. Syllabus Version 1.0, ECDL. [Online]. http://ecdl.org/media/ecdlictineducation_syllabus1.01.pdf

[30] Assessment and reporting authority (ACARA). Information and communication technology (ICT) capability. Australian Curriculum. [Online]. Available: http://www.australiancurriculum.edu.au/generalcapabilities/informati on-and-communication-technology-capability/introduction/key-ideas

[31] A. Bargfrede. Copyright law. [Online]. Available: https://online.berklee.edu/courses/copyright-law\#!syllabus

[32] American University Library. (2010). What Faculty Need to Know About Copyright for Teaching. [Online]. Available: https://www.american.edu/library/documents/upload/Copyright_for_ Teaching.pdf

[33] State Intellectual Property Office. DL-101HR General Intellectual Property Course. [Online]. Available: http://www.dziv.hr/hr/edukacija/dl-101-hr/

[34] Code Studio. Teaching computer science fundamentals. [Online]. Available: https://studio.code.org/s/K5-OnlinePD

[35] J. Gonzalez and R. Wagenaar, Tuning Educational Structures in Europe: Universities' Contribution to the Bologna Process, Bilbao: Tuning Project, 2008.

[36] R. Hartel and E. Foegeding, "Learning: Objectives, competencies, or outcomes?" Journal of Food Science Education, vol. 3, pp. 69-70, 2004.

[37] Bognar, V. Gajger, and V. Ivić, "Constructivist e-learning in higher education," Croatian Journal of Education, vol. 18, pp. 31- 46, 2016

[38] A. Ferrari. (2013). DIGCOMP: A framework for developing and understanding digital competence in Europe. [Online]. Available: http://digcomp.org.pl/wp-content/uploads/2016/07/DIGCOMP-1.0-2 013.pdf

[39] CARNet. e-Schools, "Curriculum for the enhancement of digital competences of school employees: Teachers and associates, principals and administrative staff".

[40] CARNet. Framework for the digital maturity of schools. e-Schools. [Online]. Available: https://www.e-skole.hr/en/results/digital-maturity-of-schools/framewo rk-for-the-digital-maturity-of-schools/

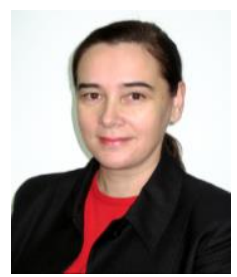

Valentina Kirinić was born in Varaždin, Croatia, on April 16, 1966. Herr educational background is a PhD in the field of information science, in 2007, a master's degree in the field of information science, in 2001 and a bachelor's degree in information systems (informatics) in 1990, all at from the Faculty of Organization and Informatics, University of Zagreb, Croatia.

She is an associate professor at the Faculty of Organization and Informatics, University of Zagreb, Croatia, after gaining nearly seven years of work experience in the IT industry. She has published research papers in national and international journals and conference proceedings and has contributed to several international and national projects. On the national level, she is a member of the Sectoral council V. Graphic technology, of the Croatian Qualifications Framework.

Assoc. Prof. Kirinić's research topics and interests include quality management, software product/information system quality, digital competencies, information literacy, ICT in education and models/frameworks of ICT professions. 


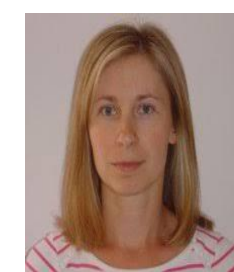

Renata Mekovec was born in Croatia, on September $5^{\text {th }}, 1978$. Her educational background is a $\mathrm{PhD}$ in the field of information and communication science in 2011, a master's degree in the field of information science in 2006 and a bachelor's degree in information systems (informatics) in 1997, all at the Faculty of Organization and Informatics, University of Zagreb, Croatia.

She is an assistant professor at the Faculty of Organization and Informatics, University of Zagreb, Croatia. She has published research papers in national and international journals and conference proceedings and has contributed several international and national projects. Her research interests lie in the fields of (1) privacy and personal data protection, (2) e-service quality and evaluation of e-service quality, (3) e-service users' perception of privacy and e-service quality.

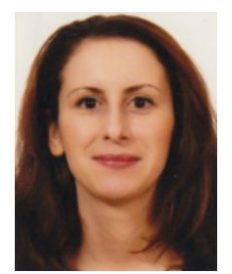

Nikolina Žajdela Hrustek was born in Croatia on December 10, 1981. She is an assistant Professor at the Faculty of Organization and Informatics, University of Zagreb, at the Department of Quantitative Methods. Her educational background is a $\mathrm{PhD}$ in the field of information science, Faculty of Organization and Informatics, University of Zagreb, Croatia, in 2015.

Asst.Prof. Žajdela Hrustek's expertise is in the area of simulation, modelling, operations research, e-learning, e-business and e-inclusion. She has published research papers in national and international journals as well as in national and international conference proceedings. 